\title{
Influence of VBA-based Monopoly Game in Microsoft Excel as Teaching Material on Primary School Students' Cross-Cultural Competence in Social Studies Learning
}

\author{
Galih Dani Septiyan Rahayu $\otimes_{1}$ \& Hana Sakura Putu Arga ${ }^{2}$ \\ 1,2 Primary School Teacher Education Study Program, IKIP Siliwangi, Cimahi City, Indonesia \\ $\bowtie$ galih040990@ikipsiliwangi.ac.id
}

\begin{abstract}
The background of this research is based on diversity of Indonesia in terms of social, cultural, religious, language and ethnic groups. The specific problem in this research lies on the diversity of students in one public elementary school in Cimahi City, situated in the area of the Indonesian Army. Therefore, this research seeks to investigate the difference in improvement of students' cross cultural skills between learning using VBA (Visual Basic of Application)-based Monopoly game teaching materials in Microsoft Excel and conventional learning. This research aims at improving students' cross cultural skills, and observing the differences or disconnection of the improvement of students' cultural skills between learning using VBA-based teaching materials and conventional learning. This research employed a quasi-experimental method with a non-randomized pretest-posttest control group design. A quantitative observation instrument in the form of a checklist was used as the research instrument. The results revealed that both learning using a teaching material of VBA-based Monopoly in Microsoft Excel and conventional learning were able to improve the students' cross cultural skills. However, based on the result of N-Gain test, learning using teaching material of VBA-based Monopoly game in Microsoft Excel was better than conventional learning.
\end{abstract}

Keywords: cross-cultural competence, diversity of Indonesia, monopoly game, teaching materials, VBA in Microsoft Excel

How to Cite: Rahayu, G. D. S., \& Arga, H. S. P. (2019). Influence of VBA-based Monopoly Game in Microsoft Excel as Teaching Material on Primary School Students' Cross-Cultural Competence in Social Studies Learning. Mimbar Sekolah Dasar, 6(2), 147-159. doi:10.17509/mimbar-sd.v6i2.16935

INTRODUCTION The level of concern of Indonesian children towards the existing cultures in Indonesia is increasingly declining. These problems are in accordance with the statement, namely 1) Indonesian children feel proud to be able to sing foreign songs and dance foreign cultural dances rather than being able to sing folk songs and dance their own cultural dances; 2) Indonesia is a country with a cultural diversity, so that it needs to be preserved in order to prevent the claiming of culture and art by other countries (Juniman, 2018; Nurhayati, 2012); and 3) Bully cases in the school environment reached $50 \%$ in 2018, brawl cases among students triggered by the absence of mutual respect from various aspects as stated by Indonesian Child Protection Commission (KPAI, Komisi Perlindungan Anak Indonesia) (Mardiana, 2018) as presented in Figure 1. 


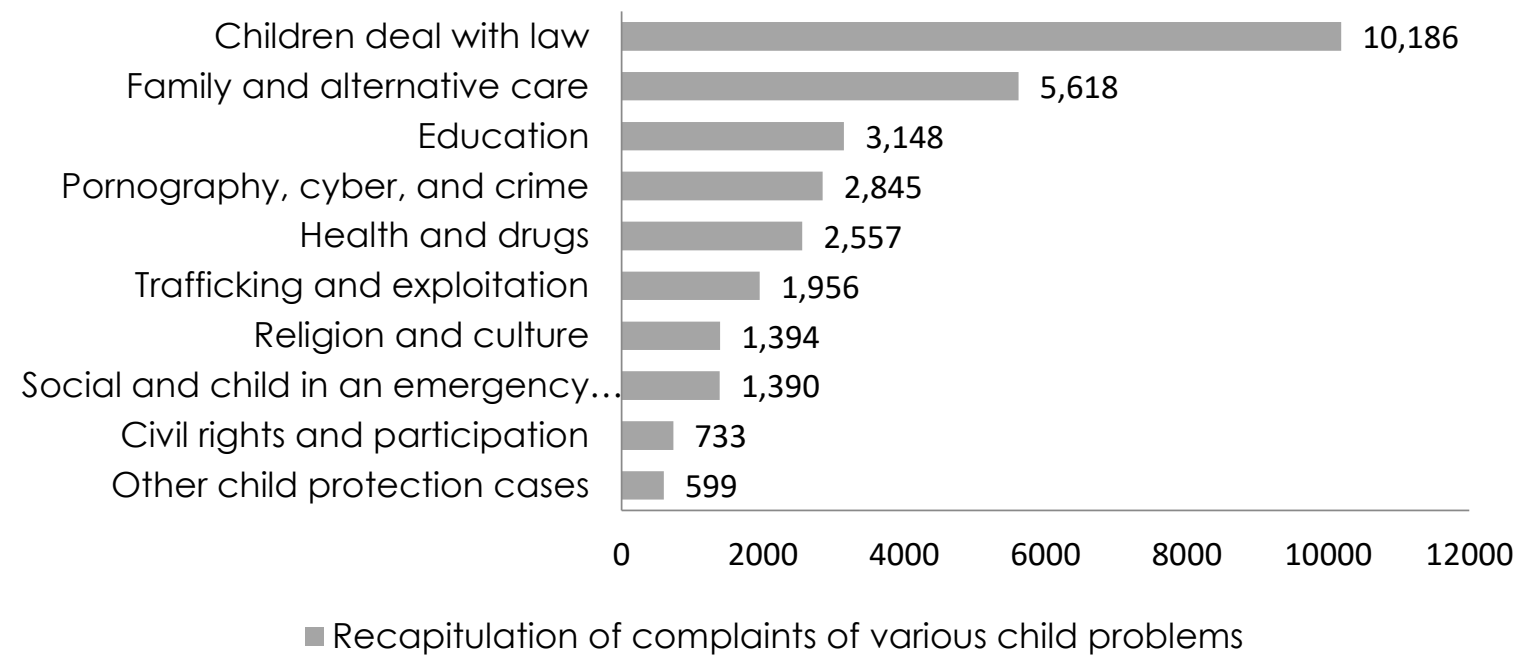

Figure 1. Recapitulation of complaints from various child problems from 2011-2018.

The aforementioned problems are caused by various factors, such as the ease of foreign cultures influences to be accepted by children in Indonesia with the help of sophisticated information technology. Lack of people's appreciation for indigenous cultures of Indonesia is also influenced by people's thinking about outdated local cultures (Kementrian Pendidikan dan Kebudayaan, 2013; Kompas, 2008; Mubah, 2011; Syaputra, Sariyatun, \& Sunardi, 2018).

In attempting to overcome the aforementioned culture-related problems, a research that focuses on a cross-cultural improvement starting from primary school students through the use of innovative learning is needed. The importance of learning in training a skill starting from the age of primary school students is based on their cognitive development, where they are in the concrete operational stage. In accordance, Kurnia (2012) states learning that can realize the diversity of material and cross-cultural competence is needed. Therefore, this research employed a VBAbased teaching material in Microsoft Excel. In addition to seeing its cognitive development, according to Syaodih (2013), since the psychological development of children is at the golden age stage, a skill in the learning process is suitable to be trained. Cross-cultural competence is a skill to work effectively and creatively with students who have different cultures to understand and accommodate social and cultural differences, and use these differences to solve existing problems (Partnership For $21^{\text {st }}$ Century, 2008; Johnson, Lenartowicz, \& Apud, 2006). Cross-cultural competence cannot be separated from the experience and training undergone by individuals in interacting with different cultures. Therefore, the training to face existing differences is needed to improve cross-cultural competence. Cross-cultural competence is the development of knowledge and skill through experience and training that 
affects a complex schema. According to Partnership For 21st Century (2008), crosscultural skills that needed to be trained and required by students are as follows.

1. Interact effectively with others.

a. Know when it is appropriate to listen and when to speak.

b. Conduct them in a respectable and professional manner.

2. Work effectively in diverse teams.

a. Respect cultural differences and work effectively with people from a different range of social and cultural backgrounds.

b. Respond open-mindedly to different ideas and values.

c. Leverage social and cultural differences to create new ideas and increase innovation and quality of work.

In addition to teaching and training crosscultural competence for primary school students, the learning using interactive learning materials and renewal technology is also required. This is in line with Voogt and Roblin (2012), stating that $21^{\text {st }}$ century skills are a new set of competences beyond the obvious information and communication technology (ICT) literacy: communication, collaboration, social and cultural skills, creativity, critical thinking, problem-solving, productivity in a globalized world, learning to learn skills, self-direction, planning, flexibility, risk taking, conflict management, and a sense of initiative and entrepreneurship.
Moreover, according to Partnership For 21 st Century (2008), the numbers of $21^{\text {st }}$ century skills comprise of thinking and problem solving, communication and collaboration, creativity and innovation, information literacy, media literacy, ICT literacy, flexibility and adaptability, initiative and self-direction, social and cross-cultural interaction, productivity and accountability, leadership and responsibility. Therefore, in this research, a learning using VBA-based monopoly game in Microsoft Excel as teaching material is considered being able to enhance students' cross-cultural competence in accordance with the $21^{\text {st }}$ century technology literacy. Moreover, by considering the judgement of Supriatna, Mulyani, and Ade (2009) and The National Council for The Social Studies (1994), this research selected social studies learning, because there are social competencies that must be mastered by students, such as skills in gathering information, communicating, self-control, numbering, solving problems, making decisions and collaborating with different teams in terms of culture, social, economic and so on. In addition, social studies in primary schools discuss cultural diversity, which found in Basic Competency (KD, Kompetensi Dasar) 3.2, that analyzes the forms of human interaction with the environment and their influence towards the social, cultural and economic development of the Indonesian people. The reasons to use VBA-based monopoly game in Microsoft 
Excel as teaching material in this research are as follows:

1. Preparation of a VBA-based monopoly game in Microsoft Excel is different compared with games on gadgets that are designed for one person. This game can involve 4-6 students.

2. This teaching material has questions that must be answered when students step on the monopoly box. That question must be answered by the students on the answer sheet. Therefore, the development of VBAbased teaching materials is not purely related to the electronic aspects, but it still considers the motoric movements of students.

3. This material teaches students honesty, sportsmanship, mutual respect, communication and cooperation.

4. This VBA-based teaching material is easily understood by teachers and students, low-cost, and can only be used on PCs and laptops. Hence, the implementation can be monitored and guided by teachers/parents.

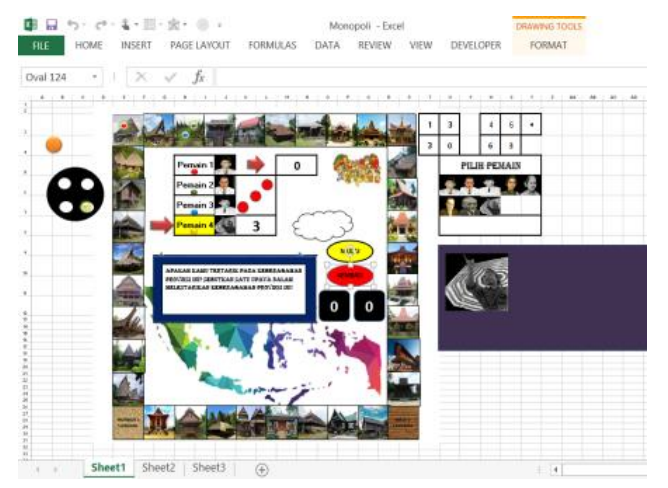

Figure 2. VBA-based Monopoly Game in Microsoft Excel as Teaching Material.
The use of a VBA-based monopoly game in Microsoft Excel as teaching material in an effort to improve students' cross-cultural competency is based on several previous studies. A research conducted by Rahayu and Nugraha (2018) regarding the effectiveness of the TGT learning model on the primary school students' cross-cultural competency in Majalengka Regency revealed that there was a significant improvement in students' cross cultural competency, The research conducted by Suparmi (2013) regarding cooperative learning in multicultural education revealed that the basis of varied group formation in cooperative learning models could develop the awareness of the importance of adaptation to the culture. Lastly, a research conducted by Chotimah, Bernard, and Wulandari (2018) entitled 'Contextual Approach Using VBA Learning Media to Improve Students' Mathematical Displacement and Disposition Ability' reveal that there was a significant improvement in the aspects of students' mathematical understanding and disposition.

The investigation to previous research shows that there are still gaps in terms of substance, because there has not been any research that seeks to improve primary school students' cross-cultural competence by utilizing renewable technologies, such as VBA applications. Therefore, the proposed research questions are: 1) How is the effect of a VBA-based Monopoly game in Microsoft 
Excel as teaching material on the fifthgrade primary school students' crosscultural competency?; 2) How is the effect of conventional learning on the fifth-grade primary school students' cross-cultural competency?; and 3) How is the comparison of students' cross-cultural improvements between students in the class using a VBA-based teaching material and students in the class using conventional learning? Therefore, this research aims at 1) investigating the effect of a VBA-based Monopoly game in Microsoft Excel as teaching material for the fifth grade primary school students' cross cultural competency; 2) investigating the effect of conventional learning on the fifth grade primary school students' cross cultural competency; and 3) investigating the comparison of students' cross cultural improvements between students in the class using a VBA-based teaching material and students in the class using conventional learning.

The abovementioned issue shows that the improvement of cross-cultural competencies in primary school students is considered significant to be conducted. Therefore, this research focuses on the influence of a VBA-based monopoly game in Microsoft Excel as teaching material on primary school students' cross-cultural competence. This is line with the previous researches that have not examined the use of a VBA-based monopoly game in Microsoft Excel as teaching materials on social competencies, especially cross- cultural competency. A research conducted by Rahayu and Nugraha (2018) regarding the effectiveness of the Teams Games Tournament (TGT) learning model on the primary school students' cross-cultural competency in Majalengka Regency revealed that there was a significant improvement in students' cross cultural competency. Moreover, a research conducted by Suparmi (2013) regarding cooperative learning in multicultural education showed that the basis of varied group formation in cooperative learning models could develop the awareness of the importance of adaptation to the culture.. In accordance a research conducted by Chotimah, Bernard, and Wulandari (2018) entitled 'Contextual Approach Using VBA Learning Media to Improve Students' Mathematical Displacement and Disposition Ability' revealed that there was an significant improvement in aspects of students' mathematical understanding and disposition.

\section{METHOD}

This research employs a quasiexperimental method with a nonrandomized pretest-posttest control group design. This method and design are considered appropriate to be employed because it aims at determining the effect of a treatment. According to Levy and J. Ellis (2011) the non-randomized pretestposttest control group design is described as follows. 
Galih Dani Septiyan Rahayu \& Hana Sakura Putu Arga, Influence of VBA-based Monopoly Game...

Table 1. Research design of the nonrandomized pretest-posttest control group.

\begin{tabular}{llll} 
Class & Pretest & Treatment & Posttest \\
\hline Experimental & 0 & $x_{1}$ & 0 \\
Control & 0 & $x_{2}$ & 0 \\
\hline
\end{tabular}

Information:

$0=$ Pretest-posttest of cross-cultural competency

$\mathrm{X}_{1}=$ Learning in experimental class using a VBA-based monopoly game in Microsoft Excel as teaching material

$\mathrm{X}_{2}=$ Learning in control class using conventional learning

This research was done in three stages: planning stage, implementation stage, and completion stage. The planning stage comprised (1) analyzing the results of previous studies regarding cross-cultural competency; (2)analyzing the development of teaching material in primary schools; (3) compiling a VBAbased monopoly game in Microsoft Excel as teaching material; (4) compiling the preparation of implementation of learning in the experimental class using a VBAbased monopoly game in Microsoft Excel; and (5) in the control class using a conventional learning, compiling the instruments, and validating the instruments. The instrument validation was conducted through validation by examining the instrument to the fifth-grade students, and the second instrument validation was conducted by experts on social skills, or primary school's social study, so that the instrument really has good validity, reliability, difficulty, and differentiation. The implementation stage comprised implementing pretest to the experimental class and control class; (2) implementing a learning using a VBA-based monopoly game in Microsoft Excel to the experimental class' and a conventional learning to the control class; and (3)implementing posttest to the experimental class and control class. The completion stage comprised (1) gathering the research data from each class; (2)processing and analyzing the research results; and (3) concluding the research results.

This research was conducted in one of the public primary schools in Cimahi City, situated in South Cimahi Sub-District with 629 heterogeneous students in terms of religions, ethnics, and cultures. This was due to the location of the students that is in the area of National Army offices. The population of this research was all fifthgrade primary school students with three classes, and 99 students. The sample of this research was the fifth-grade students from class $A$, and the fifth-grade students from class $C$ that were homogeneous in terms of average scores of social studies, the average observation results of crosscultural competency, and the number of students.

This research used observation with the indicators of cross-cultural competency. 
The selection of observation instruments was based on skills that needed to be directly observed, thus the observation was considered as appropriate research instruments. The instruments were compiled and validated to the experts and the fifth-grade primary school students to ensure the validation of instruments, and then the instruments used in the pretest and posttest stages, and processed and analyzed with the assistance of the SPPs 20 application.

\section{RESULTS}

Based on first research question, it was revealed that there was a significant improvement of cross-cultural students on the learning using a VBA-based monopoly game in Microsoft Excel. This research results were obtained through the data processing and analysis using the SPSS 20 application. The processing results are depicted in Graph 1.

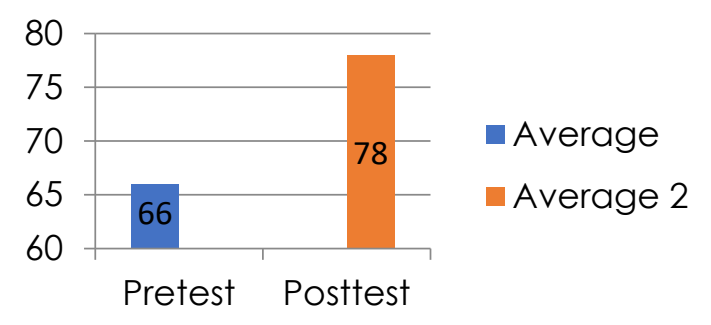

Graph 1. Average students' cross-cultural score in the experimental class.

Graph 1 depicts that there was an improvement in students' cross-cultural competency before and after being provided learning using VBA-based monopoly game in Microsoft Excel. In addition, the significant improvement can be seen from the process of statistical test with the processing results using a statistical t-test showed data sig. (2-tailed) of $0.000<0.05$, it means that there was an significant improvement of cross-cultural competency in the fifth-grade students from class A after using a VBA-based monopoly game in Microsoft Excel as teaching material. The processing results are presented in Table 2.

Table 2. T-test results of students' crosscultural competency in the experimental class.

\begin{tabular}{lccc}
\hline $\begin{array}{l}\text { T-test in } \\
\text { Experimental } \\
\text { Class }\end{array}$ & $\begin{array}{l}\text { Sig.(2- } \\
\text { tailed) }\end{array}$ & Significance & Information \\
\hline Pretest & & & \\
Posttest & 0.000 & 0.05 & Improved \\
\hline
\end{tabular}

Based on the second research question, it was revealed that there was a significant improvement of cross-cultural students on the learning using a VBA-based monopoly game in Microsoft Excel. This research results were obtained through the data processing and analysis using the SPSS 20 application. The processing results are depicted in Graph 2:

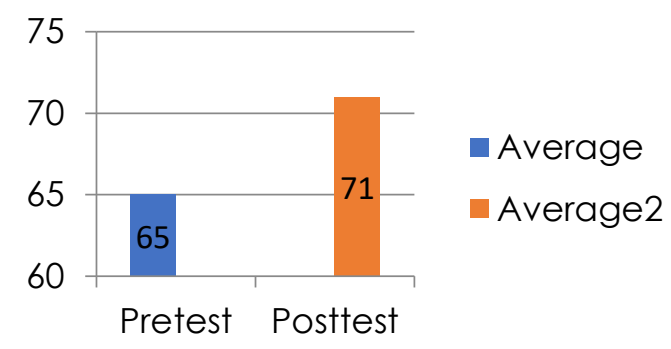

Graph 2. Average students' cross-cultural score in the control class. 
Galih Dani Septiyan Rahayu \& Hana Sakura Putu Arga, Influence of VBA-based Monopoly Game...

Graph 2 depicts that there was an improvement in students' cross-cultural competency before and after being provided conventional learning, In addition, the significant improvement can be seen from the process of statistical test with the processing results using a statistical t-test showed data sig. (2-tailed) of $0.019<0.05$, it means that there was an significant improvement in the students' cross cultural competency after learning conventional learning. The processing results are presented in Table 3.

Table 3. T-test results of students' crosscultural competency in the control class.

\begin{tabular}{llll}
\hline $\begin{array}{l}\text { T-test in } \\
\text { Control } \\
\text { Class }\end{array}$ & $\begin{array}{l}\text { Sig.(2- } \\
\text { tailed) }\end{array}$ & Significance & Information \\
\hline Pretest & & & \\
Posttest & 0. & 0.05 & Improved \\
\hline
\end{tabular}

Based on third research question, it was revealed that there was a significant improvement in students in the experimental class comparing with students in the control class. The results are depicted in Graph 3:

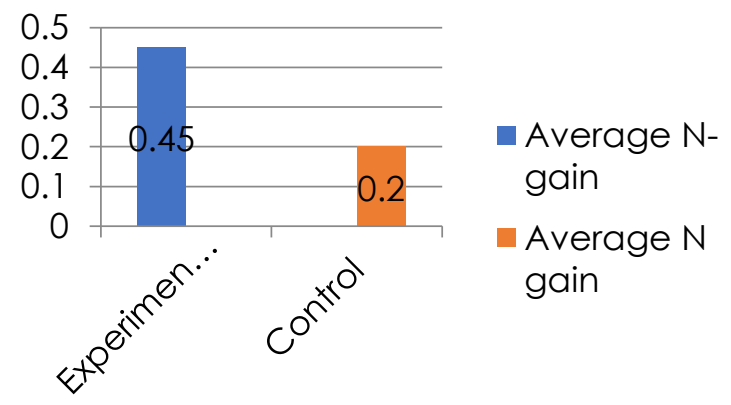

Graph 3. Average N-gain of the students' cross-cultural competency in the experimental and control classes.

Graph 2 depicts that there was a difference in average $\mathrm{N}$-gain of students' cross-cultural competency after being provided learning using VBA-based monopoly game in Microsoft Excel in the experimental class and conventional learning in the control class. In addition, the significant difference in improvement can be seen from the process of $\mathrm{N}$-gain $\mathrm{t}$ test statistics between the experimental class and the control class that is presented in Table 4.

Table 4. Results of N-gain test of students' cross-cultural competency.

\begin{tabular}{|c|c|c|c|}
\hline $\begin{array}{l}\mathrm{N} \text {-gain } \\
\text { test }\end{array}$ & $\begin{array}{l}\text { Sig. (2- } \\
\text { tailed) }\end{array}$ & Significance & Information \\
\hline $\begin{array}{l}\text { Experim- } \\
\text { ental }\end{array}$ & 0.000 & 0.05 & $\begin{array}{l}\text { There was a } \\
\text { difference in } \\
\text { improvement }\end{array}$ \\
\hline Control & & & \\
\hline
\end{tabular}

Based on the results of the data processing presented in Table 4, the value of sig. (2tailed_was $0.000<0.05$, which indicated that the learning using a VBA-based monopoly game in Microsoft Excel was better than conventional learning in improving students' cross-cultural competency.

\section{DISCUSSION}

Learning in the Experimental Class 
Learning in the experimental class used $a$ VBA-based monopoly game in Microsoft Excel as teaching material. The learning was conducted to the fifth-grade class A in primary schools with the material about interaction among human beings and its effect on the social and cultural diversity. The learning was conducted in two meetings. In the first meeting, there were some interesting findings, such as students who felt awkward in carrying out the learning using monopoly game in Microsoft Excel. This was because students were still not getting used to utilize information and communications technology (ICT) teaching tools or materials (Fu, 2013; Soewarno, Hasmiana, \& Faiza, 2016). In addition to the awkwardness because the use of ICTbased teaching material, some students felt awkward in playing monopoly game because they were not getting used to collaboratively learn with new groups (not with their close friends). It occurred because students were used to work in group with their close friends (Gafoor \& Kurukkan, 2015; Ghavifekr, Kunjappan, Ramasamy, \& Anthony, 2016).

The findings of the first meeting were analyzed and improved at the second meeting. Improvements were conducted, including to plan the learning more optimally and explain the steps of playing game more simply and clearly, so that students were not awkward anymore in playing a VBA-based monopoly game in Microsoft Excel. In the second meeting, students were divided into different groups. This was conducted with the aims of training students in working, communicating, and respecting together with other students, not only with their close friends. This was in line with the statement that learning using group strategies can train students to be able to cooperate and respect other students, and this grouping made the students got used to this technique and became more enthusiastic to learn compared with their first meeting (Bachroni, 2011; D. W. Johnson \& Johnson, 2009; Setiyanti, 2012). From these improvements in the second meeting, the result obtained was good in accordance with the result section in which the learning using a VBA-based monopoly game in Microsoft Excel was able to improve students' cross-cultural competency.

\section{Learning in the Control Class}

Learning in the control class was conducted in two meetings in the fifthgrade class $C$ in primary schools using the conventional learning. This conventional learning means using the usual method conducted in the class by using students' worksheets (LKS, Lembar Kerja Siswa) in the form of puzzles. In this learning, students carried out puzzles in group. In the first meeting, there was not any obstacle or finding, because the students learned with the usual media or strategy that carried out by the teacher on daily learning. However, there was an interesting finding that emerged in the first meeting in which 
Galih Dani Septiyan Rahayu \& Hana Sakura Putu Arga, Influence of VBA-based Monopoly Game...

some students (excellent group students) seemed lazy and bored when working on LKS.

Based on the direct interview results when learning it, the students considered that their assignment in answering the LKS was easy and not challenging. This was in line with the statement of the ordinary learning and lack of teacher's creativity in carrying out learning caused students to easily get bored (Dunlosky, Rawson, Marsh, Nathan, \& Willingham, 2013). Furthermore, this finding was improved in the second meeting by making a puzzle in LKS with an attractive features and discussion questions that were clearer and more meaningful than the puzzle in the first meeting.

Moreover, student grouping was improved by dividing students into different groups, because the habits of the previous teacher created the group for one semester, so students were getting used in groups with the same students continuously. The results of the improvement in learning in the second meeting showed a positive effect, which was seen from an increase in students' cross cultural competency compared to the results of the pretest, but there were still some students who were not enthusiastic during the implementation of learning because they were not grouped in the same group (Bachroni, 2011; D. W. Johnson \& Johnson, 2009; Macpherson, 2007).
Based on the results and discussion, this research provided the following implications:1) a learning using VBA-based monopoly game in Microsoft Excel as teaching material was able to improve the fifth-grade students' cross-cultural competency, especially in the material about the interactions among human beings based on its diversity and effect on the social and cultural development; 2) a learning using this VBA-based material was conducted in accordance with the technological development that gradually developed, and the characteristics of primary school students who were excited in carrying out the games; 3) a learning using VBA-based monopoly game in Microsoft Excel as teaching material affected students' appreciation to other students, fostered cooperation during learning, grew boldness in expressing opinions, and accepted differences between students that were expected to be applied in their daily life, so that the individualist attitude in students could be minimized; and 4) a learning using VBAbased monopoly game in Microsoft Excel as teaching material could be used as a source or basis of learning in primary school because it had many advantages described in the findings and explanation in this research.

\section{CONCLUSION}

This research concluded that 1) a learning using VBA-based monopoly game in Microsoft Excel as teaching material was able to improve the fifth-grade of primary 
school students' cross-cultural competency; 2) a learning using VBAbased monopoly game in Microsoft Excel as teaching material was better than the conventional learning in improving the fifth-grade of primary school students' cross-cultural competency in social studies learning; 3) the teaching material must be well-prepared to motivate students in accordance with student characteristics and the material being taught; 4) high creativity was needed in implementing learning to respond to unpredictable students' responses, such as grouping students that made them less enthusiastic to learn.

\section{RECOMMENDATION}

The recommendation for other researchers who will conduct or examine a research related to cross cultural competency and VBA-based teaching materials in Microsoft Excel is by involving of a wider sampling to cover a broader generalization research so that it can develop a VBA-based teaching materials, and the VBA-based application can be more utilized in learning activities and more useful for learning, especially in primary schools.

\section{ACKNOWLEDGMENTS}

Thanks to Directorate General of Research and Development Reinforcement of Ministry of Research, Technology and Higher Education who have provided the funds to conduct the research through a research program for beginner lecturers, thus this research can be conducted properly in accordance with its target and goal.

\section{REFERENCES}

Bachroni, M. (2011). Pelatihan Pembentukan Tim untuk Meningkatkan Kohesivitas Tim pada Kopertis $\vee$ Yogyakarta. JURNAL PSIKOLOGI, 12.

Century, Partnership For 21st, C., Partnership For 21st. (2008). 21st century skills, education, and competitiveness. A resourche and policy guide. Tucson: Partnership For 21 st Century.

Chotimah, S., Bernard, M., \& Wulandari, S. M. (2018). Contextual approach using VBA learning media to improve students' mathematical displacement and disposition ability. Journal of Physics: Conference Series, 948, $012025 . \quad$ https://doi.org/10.1088/17426596/948/1/012025

Dunlosky, J., Rawson, K. A., Marsh, E. J., Nathan, M. J., \& Willingham, D. T. (2013). Improving Students' Learning With Effective Learning Techniques: Promising Directions From Cognitive and Educational Psychology. Psychological Science in the Public Interest, 14(1), 4-58. https://doi.org/10.1177/1529100612453 266.

Fu, J. (2013). Complexity of ICT in education: A critical literature review and its implications. International Journal of education and Development using ICT, 9(1), 112-125.

Gafoor, K. A., \& Kurukkan, A. (2015). Learner and Teacher perception on Difficulties in Learning and Teaching Mathematics: Some Implications. 13. Retrieve from https://eric.ed.gov/?id=ED568368

Ghavifekr, S., Kunjappan, T., Ramasamy, L., \& Anthony, A. (2016). Teaching and Learning with ICT Tools: Issues and Challenges from Teachers' Perceptions. 4 (2), 20.

Johnson, D. W., \& Johnson, R. T. (2009). An Educational Psychology Success Story: 
Social Interdependence Theory and Cooperative Learning. Educational Researcher, 38(5), 365-379. https://doi.org/10.3102/0013189X09339 057

Johnson, J. P., Lenartowicz, T., \& Apud, S. (2006). Cross-cultural competence in international business: Toward a definition and a model. Journal of International Business Studies, 37(4), 525-543.

https://doi.org/10.1057/palgrave.jibs.8 400205

Juniman, P. T. (2018). Indonesia Kumpulkan Bukti Kuda Lumping yang Diklaim Malaysia. CNN Indonesia. Retrieved from

https://www.cnnindonesia.com/hibur an/20171005084029-241-

246243/indonesia-kumpulkan-buktikuda-lumping-yang-diklaim-malaysia

Kementrian Pendidikan dan Kebudayaan, K. P. dan K. (2013). RENCANA INDUK NASIONAL PEMBANGUNAN KEBUDAYAAN 2010 - 202. Kementrian.

Kompas, K. (2008). Generasi Muda Kurang Peduli Budaya Sendiri Artikel ini telah tayang di Kompas.com dengan judul "Generasi Muda Kurang Peduli Budaya Sendiri", https://nasional.kompas.com/read/20 08/11/26/17323361/generasi.muda.kur ang.peduli.budaya.sendiri. Kompas Online. Retrieved from https://nasional.kompas.com/read/20 08/11/26/17323361/generasi.muda.kur ang.peduli.budaya.sendiri.

Kurnia, I. (2012). Perkembangan Belajar Peserta Didik. Jakarta: Direktorat Jenderal Pendidikan Tinggi Departemen Pendidikan Nasional.

Levy, Y., \& J. Ellis, T. (2011). A Guide for Novice Researchers on Experimental and Quasi-Experimental Studies in Information Systems Research. Interdisciplinary Journal of Information, Knowledge, and Management, 6 , 151-161. https://doi.org/10.28945/1373

Macpherson, A. (2007). Cooperative Learning Group Activities for College Courses. 205. Retrieve from https://kora.kpu.ca/islandora/object/ kora:43/datastream/PDF/view
Mardiana, R. (2018). Kekerasan terhadap anak dan remaja. Jakarta: InfoDatin (Pusat informasi dan data kemetrian kesehatan RI).

Mubah, A. S. (2011). Strategi Meningkatkan Daya Tahan Budaya Lokal dalam Menghadapi Arus Globalisasi. Masyarakat, Kebudayaan dan Politik UNAIR, 24(4), 8.

National Council for The Social Studies, N. C. for T. S. S. (1994). Curriculum standarad for the social studies. Washington, DC: The National Council for The Social Studies.

Nurhayati, N. (2012, June). Reaksi atas Tor Tor dan Gordang Sembilan. BBC News Indonesia. Retrieved from https://www.bbc.com/indonesia/foru m/2012/06/120618_forum_tortor.shtml

Rahayu, G. D. S., \& Nugraha, F. F. (2018). EFFECT OF COOPERATIVE LEARNING MODEL TYPE TEAM GAME TOURNAMENT (TGT) ON CROSSCULTURAL SKILLS IN LEARNING SCIENCE SOCIAL KNOWLEDGE IN PRIMARY SCHOOL. PrimaryEdu - Journal of Primary Education, 2(1), 63. https://doi.org/10.22460/pej.vli1.671

Setiyanti, S. W. (2012). JURNAL STIE SEMARANG, VOL 4, NO 3, Edisi Oktober 2012 (ISSN: 2252-7826). 4(3), 7.

Soewarno, S., Hasmiana, H., \& Faiza, F. (2016). KENDALA-KENDALA YANG DIHADAPI GURU DALAM MEMANFAATKAN MEDIA BERBASIS KOMPUTER DI SD NEGERI 10 BANDA ACEH. JURNAL PESONA DASAR, 2(4), 28-39.

Suparmi, S. (2013). Pembelajaran Kooperatif dalam Pendidikan Multikultural. Jurnal Pembangunan Pendidikan: Fondasi dan Aplikasi, 1 (1). https://doi.org/10.21831/jppfa.v1i1.105 5

Supriatna, N., Mulyani, S., \& Ade, R. (2009). Pendidikan IPS SD. Bandung: UPI Press.

Syaodih, E. (2013). Pendidikan Anak Usia Dini. Bahan Pelatihan Pembelajaran Terpadu Yayasan Pendidikan Salman Al Farisi. Bandung. 
Syaputra, E., Sariyatun, S., \& Sunardi, S. (2018). The Strategy of Enhancing Student's Social Awareness through History Learning Based on Selimbur Caye Oral Tradition Values. International Journal of Multicultural and Multireligious Understanding, 5(4), 22.

https://doi.org/10.18415/ijmmu.v5i4.16 1

Voogt, J., \& N.P, R. (2012). A comparative analysis of international frameworks for 21st century competences: Implications for national curriculum policies. 44 (3), 299-321. 